\title{
Frank Scott's University of Dystopia, 1924
}

\section{by Robert H. Michel}

A $s$ self-contained micro-societies, universities make ideal settings for dystopias and unpleasant visions of the future, whether the theme is social formation, sexual freedom, political slavery or debasement of learning. Yet while satires abound, for example those by Tom Sharpe, memorable dystopian fiction set in university or analogous settings is rarer: one thinks of John Barth's Giles Goat-Boy (1966) or the less ambitious yet striking No Transfer (1979) by Stephen Walton, where students with failing grades, including a girl fresh from lovemaking in her dorm, are selected randomly and guillotined.

In November 1924, law student (and future professor and poet) Frank Scott (BCL 1927) published a brief satirical story in the McGill Daily Literary Supplement about a futuristic university. An appropriate vehicle for satire, the Literary Supplement became one of the earliest forums for modernist Canadian poetry and prose as well as jabs against established social and university mores. The innocent inspiration for Scott's take-off was the University of Pittsburgh's recently projected "Cathedral of Learning," a skyscraper tower capable of housing an entire university. From the Cathedral, Scott extrapolated an invented university which was mildly but ominously prophetic of modern totalitarianism and computer technology in its use of automated tickets, indexes, reports and officials to track and control each minute and movement of a student's day. Newly-arrived McGill French professor Régis Messac later spoofed the Daily and student literary journals in Smith Conundrum, his satirical novel about McGill. He almost certainly would have read Scott's satire and been amused by Scott's visions of future automated student life; "American" universities' mindless efficiency and emphasis on bigness; the curriculum of subjects from Pragmatism to Propagandism; and the higher floors "nearest Heaven" which were "devoted to Theology, Clan Government and kindred topics." As Scott's fellow student writer Leon Edel (BA 1927, MA 1928) recalled, Scott's article, offered a "Wellsian peep at the future ... far ahead of Orwell."

In 1914, in his satirical novel Arcadian Adventures with the Idle Rich, Stephen Leacock had already postulated a 15 story skyscraper on his thinly disguised McGill campus. The public mistook the building for a factory since it had machinery running full blast for technical studies; its students even dressed in overalls. Scott may have recalled Leacock's notion when he developed in more detail the dynamics of a university that was vertical. However, architectural reality outdid fiction: Pittsburgh's real life Cathedral of Learning, built from 1926 to 1937, would reach much higher than Leacock's invention-to 42 stories. Moreover, unlike Leacock's students, the Cathedral's students, as imagined by Scott, were closely regulated. Scott produced a dual spoof-architectural and social. From the spark of the soon to be built, vertical skyscraper university in Pittsburgh, he imagined the restricted student life such a building might have spawned six decades in the future.

Scott uses the time honored device of traveling through a time machine (hidden in a cave on Mount Royal) to reach the year 1985. Then he catches an airplane to Pittsburgh. There, he finds the Cathedral tower swarming with students who are attended by helpful but bossy officials. He is told to register and pushing the buttons of a timer clock finds himself issued with a ticket reading: "STUDENT NO. 9999 SUBJECT Pisciculture FLOOR 14 ROOM K5 SEAT 421 DATE Nov. 15 '85 TIME 10.01 A.M. All tickets to be filed before leaving." ${ }^{3} \mathrm{He}$ jumps on one of the many speeding elevators but it is the wrong one; it goes nonstop to the Philosophy floor not to Pisciculture [fish breeding]. A student takes him into a lounge and clues him in about the university:

Let metellyou at once that you are now in the greatest, in fact the only, Cathedral of learning in the world. This lounge is higher above ground than the dome of St. Peter's; there is more stone in this building than in the Great Pyramid; we have a larger number of students than any two Continental Universities; we turn out more graduates in a year than Oxford and Cambridge do in five; we have faster elevators and greater office space than the Woolworth building. In this majestic educational skyscraper there are four miles of corridors, nine dance-halls, 14 gymnasiums and 735 pure Gothic doorways. We manufacture everything used in this building, for whatever purpose, in our own workshops-yes, everything from tobacco to text-books. ${ }^{4}$

Scott's new acquaintance boasts the university teaches every possible subject. Its Research Department constantly develops new studies. Fifty-two different degrees are offered-one for each floor of the building.

Not a moment of the undergraduate's time is wasted. By the card-index system we can account for every minute of his day. If he fails to reach his lecture before the door is locked, he must report within five minutes to the nearest gymnasium for an hour's drill. By our speedy elevators we have reduced to a 
minimum the time required to go from lecture to lecture. Even when his hour of recreation is due, he must obtain a certificate of attendance in the Lounge set apart for students following courses similar to his own so that his conversation may run on lines similar to his work. ${ }^{5}$

The student notes that he will credit his talk with Scott on his (the student's) attendance card as "Propagandism" and takes it to be signed for credit by one of the omnipresent officials. Scott flees, fearing his heart will not take any more strain. Like many dystopias - and indeed like many utopias - there is an atmosphere of enthusiastic but robot-like existence in what is close to being a prison. Scott, like Leacock and Messac, portrays American university education as preoccupied with technology, expanding physical plants, and-most of all-an engrained boosterism, which graduates could apply whether they went on to selling cars or entering the ministry. One wonders if Scott and Messac ever met, from 1924 to 1927, when they were at McGill. Both ridiculed sacred cows, especially the university and its administrators; both continued to rock the boat of authority as they grew older.

\section{ENDNOTES}

${ }^{1}$ F.R. Scott, "The Cathedral of Learning," McGill Daily Literary Supplement, Vol. I, No. 7, 19 November 1924, 1, 4. In a few years, Messac would write his university satire (examined elsewhere in this volume). Apparently, he was not yet interested in the dystopian science fiction at which he would excel in the 1930s. His novel about McGill does not portray the future nor was it likely influenced by Scott's article.

${ }^{2}$ Leon Edel, "The Young Warrier in the Twenties," On F.R. Scott, ed. Sandra Djwa and R. St J. Macdonald, McGill-Queen's University Press, Kingston and Montreal, 1983, 10. See also Sandra Djwa, The Politics of the Imagination: a Life of F.R. Scott, McClelland and Stewart, Toronto 1987, 85.

${ }^{3}$ Scott, "Cathedral," 1.

${ }^{4}$ Scott, "Cathedral," 1, 4.

${ }^{5} \mathrm{~S}$ cott, "Cathedral," 4 . The building as originally planned was to have had the 52 stories to which Scott's fictional student refers. Its architect was Charles Z. Klauder (1872-1938), famous archiect of grandiose university buildings. The exterior and interior designs are usually described as gothic. The building has 42 stories and a height of $163 \mathrm{~m}$. The building was partly funded by public donations; school children were asked to give ten cents to "buy a brick." It was the world's tallest building devoted to education until it was surpassed by Moscow University's tower (1949-1953) of 36 stories topped by a spire, $240 \mathrm{~m}$ high. 